\title{
Folyóiratunk olvasottsági eredményei
}

\author{
The journal's popularity
}

doi: 10.24365/ef.v60i2.466

A szerkesztőség örömmel tapasztalja, hogy mind a lap olvasói bázisa, mind a közlésre benyújtott kéziratok száma folyamatosan növekszik. Havi látogatóink száma már több hónapja eléri a 10 ezret, az elmúlt hónap pedig már a második, amikor naponta átlagosan több mint 300-an kattintottak weboldalunkra. A látogatói és olvasottsági statisztikákat a megszokott táblázatban és ábrán mutatjuk be részletesen alább.

Összességében elmondhatjuk, hogy az iskolai egészségfejlesztés és az egészséges táplálkozás témákban megjelent cikkek nyerik el a legnagyobb érdeklődést. Folyamatosan magas olvasottságot érnek el a cikkismertetések, köszönhető ez valószínúleg annak, hogy a rövid közleményekben az ismertetők nemzetközi szakirodalomból mutatnak be fontosnak tekinthető kutatási eredményeket, jó példákat stb.

Vitaindító közleményünkhöz és a többi cikkhez is várjuk a hozzászólásokat, véleményeket. Köszönjük szerzőinknek a kiváló írásokat, olvasóinknak pedig a figyelemreméltó érdeklődést.

\section{1. ábra: A folyóirat honlapját havonta, illetve naponta átlagosan meglátogatók száma}

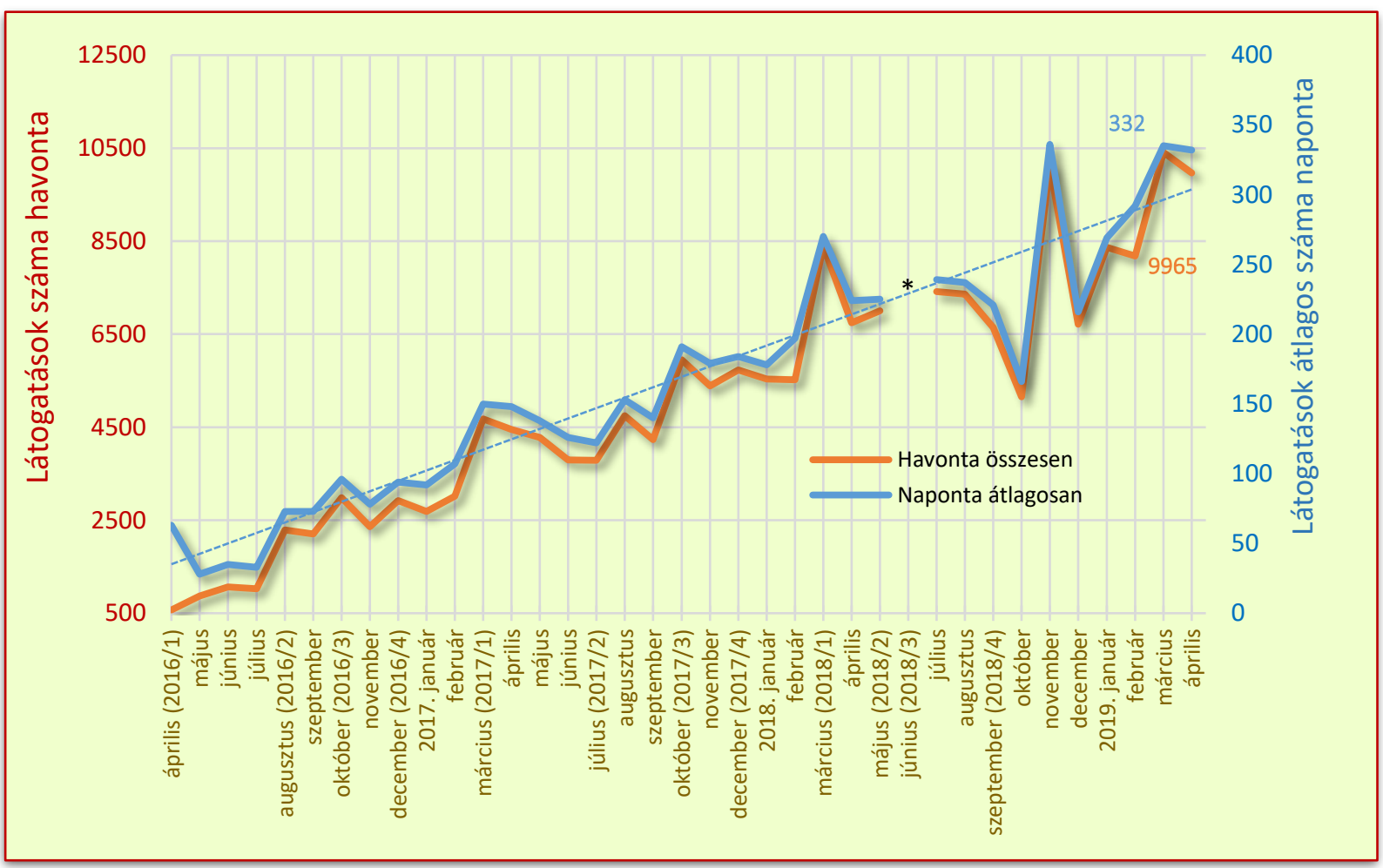

* nincs adat 


\section{1. táblázat: TOP 10-es rangsor}

\begin{tabular}{|c|c|c|c|}
\hline $\begin{array}{l}\text { Megte- } \\
\text { kintések } \\
\text { száma }\end{array}$ & Közlemény címe & Szerzők & Lapszám \\
\hline \multicolumn{4}{|c|}{ ÖSSZEFOGLALÓ } \\
\hline 754 & Egészséges életmóddal kapcsolatos kutatások a hazai iskolákban & $\begin{array}{l}\text { Járomi É, Szilágyi K, } \\
\text { Vitrai J }\end{array}$ & 2016. 1. \\
\hline 643 & A kortársbántalmazás (bullying) mint népegészségügyi probléma & $\begin{array}{l}\text { Várnai D, Zsíros E, } \\
\text { Németh Á }\end{array}$ & 2016. 4. \\
\hline 617 & Hazai egészség-pillanatkép, 2017 & $\begin{array}{l}\text { Vitrai J, Bakacs M, } \\
\text { Varsányi P }\end{array}$ & 2017. 4. \\
\hline 526 & $\begin{array}{l}\text { A 2015/2016. tanév országos fittségmérési eredményei a Nemzeti Egységes Tanulói Fittségi } \\
\text { Teszt (NETFIT }{ }^{\circledR} \text { ) alapján }\end{array}$ & Csányi T, Kaj M & 2017. 4. \\
\hline 505 & $\begin{array}{l}\text { A gyógytestnevelés jelentősége a szekunder rehabilitáció és egészségfejlesztés folyamatában, } \\
\text { megújulásának szükségessége, irányai }\end{array}$ & Simon I, Kajtár G & 2018. 1. \\
\hline 497 & $\begin{array}{l}\text { Kortárs egészségfejlesztési programok gyermekek és fiatalok körében a hazai és a nemzetközi } \\
\text { szakirodalom tükrében - Szisztematikus áttekintés }\end{array}$ & Lukács-Jakab Á et al. & 2018. 1. \\
\hline 471 & A magyarországi egészségértés nemzetközi összehasonlításban & Kolta J, Kun E & 2016. 3. \\
\hline 450 & Magyarország népegészségügyi rendszere és egészségfejlesztéssel foglalkozó szervezetei & Túri G et al. & 2018. 2. \\
\hline 449 & $\begin{array}{l}\text { Egészpályás letámadás a kövérség ellen - Komplex beavatkozásokkal az elhízás visszaszorítá- } \\
\text { sára }\end{array}$ & Vitrai J, Bakacs M & 2017. 4. \\
\hline 444 & Az egészségműveltség definíciói & Csizmadia P & 2016. 3. \\
\hline \multicolumn{4}{|c|}{ TELES KÖZLEMÉNY } \\
\hline 2947 & A csecsemőkori allergia-megelőzés korszerű irányelvei és lehetőségei & Réthy A & 2017. 1. \\
\hline 1232 & Egészségfejlesztési Irodák hálózata & Bezzegh P & 2016. 1. \\
\hline 1057 & Egészséges életmóddal kapcsolatos kutatások a hazai iskolákban & $\begin{array}{l}\text { Járomi É, Szilágyi K, } \\
\text { Vitrai J }\end{array}$ & 2016. 1. \\
\hline 646 & Hazai egészség-pillanatkép, 2017 & $\begin{array}{l}\text { Vitrai J, Bakacs M, } \\
\text { Varsányi P }\end{array}$ & 2017. 4. \\
\hline 623 & OKOSTÁNYÉR ${ }^{\circledR}$ - új táplálkozási ajánlás a hazai felnőtt lakosság számára & Szűcs Zs & 2016. 4. \\
\hline 533 & Magyarország népegészségügyi rendszere és egészségfejlesztéssel foglalkozó szervezetei & Túri G et. Al & 2018. 2. \\
\hline 398 & $\begin{array}{l}\text { Összefoglaló „A munkahelyi egészségfejlesztés általános szervezeti megvalósítására vonat- } \\
\text { kozó szakmai útmutató”-ról }\end{array}$ & Solymossy J, Koós T & 2016. 3. \\
\hline 388 & Amerikai Táplálkozási Ajánlás 2015-2020 - rövid ismertetés & Fekete K, Henter I & 2016. 2. \\
\hline 379 & Az iskolai egészségfejlesztés hazai és nemzetközi szemléletének bemutatatása & Járomi É, Vitrai J & 2017. 1. \\
\hline 358 & A kortársbántalmazás (bullying) mint népegészségügyi probléma & $\begin{array}{l}\text { Várnai D, Zsíros E, } \\
\text { Németh Á }\end{array}$ & 2016. 4. \\
\hline \multicolumn{4}{|c|}{ "ÉRDEKESSÉG" } \\
\hline 3,83 & A csecsemőkori allergia-megelőzés korszerű irányelvei és lehetőségei & Réthy A & 2017. 1. \\
\hline 2,30 & A személyi edzői hivatás tudományos és szakmai aspektusai & Tánczos Z, Bognár J & 2019. 1. \\
\hline 2,03 & A fizikai aktivitás, mint egészségbefektetés & $\begin{array}{l}\text { Pfau Christa, Pető Károly, } \\
\text { Bácsné Bába Éva }\end{array}$ & 2019. 1. \\
\hline 1,49 & Magyarország népegészségügyi rendszere és egészségfejlesztéssel foglalkozó szervezetei & Túri G et al. & 2018. 2. \\
\hline 1,49 & $\begin{array}{l}\text { Egészségmagatartás összehasonlító vizsgálata az orvostanhallgatók és jogászhallgatók köré- } \\
\text { ben }\end{array}$ & $\begin{array}{l}\text { Dombrádi V, Czira E, } \\
\text { Gáll T, Nagy A, Bíró K }\end{array}$ & 2019. 1. \\
\hline 1,30 & $\begin{array}{l}\text { Energiaital fogyasztási szokások és egészségtudatosság a felsőfokú képzésben résztvevő hall- } \\
\text { gatók körében }\end{array}$ & $\begin{array}{l}\text { Dojcsákné Kiss-Tóth É, } \\
\text { Kiss-Tóth E }\end{array}$ & 2018. 4. \\
\hline 1,29 & Hazai egészség-pillanatkép, 2017 & $\begin{array}{l}\text { Vitrai J, Bakacs M, } \\
\text { Varsányi P }\end{array}$ & 2017. 4. \\
\hline 1,24 & Tematikus cikkválogatás az egészséges táplálkozás területéről & szerkesztőség & 2018. 6. \\
\hline 1,15 & A fizikai inaktivitás nemzetgazdasági terhei & $\begin{array}{l}\text { Gabnai Z, Müller A, } \\
\text { Bács Z, Bácsné Bába É }\end{array}$ & 2019. 1. \\
\hline 1,13 & Tematikus cikkválogatás az iskolai egészségfejlesztés területéről & szerkesztőség & 2019. 1. \\
\hline
\end{tabular}

